\title{
Identification of Secondary Metabolites from Ethanol Extract of Ciplukan (Physalis angulate) Leaves and Toxicity Test on Post-Larvae of Tiger Shrimp (Penaeus monodon)
}

\section{Identifikasi Senyawa Metabolit Sekunder Ektrak Etanol Daun Ciplukan (Physalis angulata) dan Uji Toksisitas terhadap Sintasan Post Larva Udang Windu (Penaeus monodon)}

\author{
Awaludin $^{1^{*}}$, Yulma² $^{2}$ dan Kartina ${ }^{1}$ \\ ${ }^{1}$ Department of Aquaculture, Faculty of Fisheries and Marine Science, Universitas Borneo Tarakan. Tarakan, Indonesia. \\ 2 Department of Aquatic Resources Management, Faculty of Fisheries and Marine Science, Universitas Borneo Tarakan. Tarakan, Indonesia.
}

\section{ARTICLE INFO}

Received: Juny 22, 2019

Accepted: October 20, 2019

*) Corresponding author:

E-mail: awaludin@borneo.ac.id

Keywords:

cutleaf groundcherry leaves, secondary metabolites, post-larvae of tiger prawns, toxicity

Kata Kunci:

daun ciplukan, metabolit sekunder, post larva udang windu, toksisitas

\section{Abstract}

Physalis angulata is a garden plant that has been widely used as a medicinal plant by the community. This plant contains secondary metabolites that can be used as medicine and nutrition enhancement. This study aims to identify the secondary metabolite compounds and their toxicity to the post-larva (PL) survival rate in tiger prawns. This study was conducted in several stages (1). P. angulata extraction using ethanol, (2) $P$. angulata GCMS test, (3) The identification of the secondary metabolites from $P$. angulata (4) LC50 test (Lethal Concentration 50) and (5) Data analysis. Based on the results of GCMS analysis, it was indicated that $P$. angulata contained the secondary metabolite compounds, including phenols, steroids, fatty acids, terpenoids, benzenes, and alkaloids. It is concluded that the compounds contained are presumed to be beneficial for prawn farming development in terms of disease prevention, growth acceleration, and egg quality improvement. Meanwhile, the toxicity test results by using tiger prawn larvae for 48 hours revealed that the safe concentration level used for prawn development by utilizing the cutleaf groundcherry extract was at $13.1 \mathrm{mg} / \mathrm{l}$.

\section{Abstrak}

Physalis angulata merupakan tumbuhan pekarangan yang telah banyak dimanfaatkan sebagai tumbuhan obat oleh masyarakat. Tumbuhan ini diduga memiliki metabolit sekunder yang dapat dimanfaatkan sebagai obat dan peningkatan nutrisi. Penelitian ini bertujuan untuk mengindentifikasi senyawa metabolik sekunder dan toksisitasnya terhadap sintasan post larva (PL) udang windu. Penelitian ini dilakukan dengan beberapa tahapan (1). Ekstraksi $P$. angulata dengan menggunakan etanol, (2) Uji GCMS P. angulata, (3) Identifikasi metabolit sekunder dari P. angulata (4) $\mathrm{Uji}_{\mathrm{LC}_{50}}$ (Lethal Concentration 50) dan (5) Analisis data. Berdasarkan hasil analisis GCMS menunjukkan bahwa P. angulata mengandung metabolit sekunder golongan senyawa antara lain fenol, steroid, asam lemak, terpenoid, benzene dan alkaloid. Senyawa- senyawa yang terkandung tersebut diduga dapat dijadikan sebagai pengembangan budidaya udang pada penanggulangan penyakit, percepatan pertumbuhan dan peningkatan kualitas telur. Sedangkan hasil uji toksisitas dengan menggunakan larva udang windu selama 48 jam menunjukkan bahwa konsentrasi aman yang dapat digunakan untuk pengembangan udang dengan memanfaatkan ekstrak ciplukan dengan konsentrasi 13,1 mg/l.

Cite this as: Awaludin, Yulma, \& Kartina. (2019). Identification of Secondary Metabolites from Ethanol Extract of Ciplukan (Physalis angulate) Leaves and Toxicity Test on Post-Larvae of Tiger Shrimp (Penaeus monodon). Jurnal Ilmiah Perikanan dan Kelautan, 11(2):92-99. http://doi.org/10.20473/jipk.v11i2.13162 


\section{Introduction}

Prawn farming is one of the most essential aquaculture industries globally. Based on the FAO data (2017), prawn farming production resulted in 2.9 million tons globally in 2016, and approximately $75 \%$ of production emanated from Asia-Pacific. Prawn production in Indonesia reaches 390 tons. Prawn production in Indonesia does not increase significantly compared to the previous years. This situation can be influenced by slow growth, disease, and environmental factors. One of the prawn types produced in Indonesia is the tiger prawns (Peaneus monodon) which production has decreased because the farmers switch to white leg shrimp (Litopenaeus vannamei) farming.

The urge to breed tiger prawns has decreased due to various problems, such as disease, slow growth, and the low number of egg production from mature prawns with mature gonads (Nawang et al., 2015). Antibiotics are used to prevent bacterial diseases on tiger prawns in ponds. The use of antibiotics in aquaculture water leads to bacterial resistance against antibiotics. Furthermore, the accumulation of antibiotics in the prawn body causes the prawn to not sell well in the international market.

The growth of tiger prawns is followed by the moulting process. Moulting is a phenomenon that is found in many crustaceans and other invertebrates where old cuticles accumulate and produce new cuticles. Tiger prawn is a crustacean with a shell in which its growth is accompanied by moulting. The moulting stage is first determined by changes in physical criteria, followed by the deposition of collagen fibers, carbohydrates, lipids, and calcium salts in tissues throughout the moulting cycle (Waraporn et al., 2005). The moulting cycle includes moult, postmoult, intermoult and premoult (Kuballa and Elizur, 2007). In the development of the prawn cycle at a time when hormones are activated between the hormone Moult Inhibiting Hormone (MIH) and Moult Stimulating Hormone (MSH), both hormones are mediated by fatty acids such as sterols. Wen Xia Bo et al., (2003) report that tiger prawns have limited ability in elongation and desaturation of Polyunsaturated Fatty Acid (PUFA) to Highly Unsaturated Fatty Acid (HUFA). Tiger prawns can obtain fatty acids from diets containing fatty acids.

The attempts to increase the gonad maturity in tiger prawns include feeding them with high protein feed and ablation. The increased levels of protein in feed have been able to increase the development of ovaries in freshwater crayfish (Cherax quadricarinatus). The cost of the nutrient provision in feed containing high protein for tiger prawn reproduction is relatively expensive. Meanwhile, ablation can increase the spawning rate in tiger prawn broodstocks (Wulandari et al., 2010). However, it hinders the prawn ability in regulating various physiological processes (Huberman, 2000). Ridwan et al., (2015) propose that the use of natural materials could increase the rate of ovarian development in whiteleg shrimps (Litopenaeus vannamei) through the use of lanosterol in rose myrtle. Lanosterol forms cholesterol in plants. Cholesterol is one of the chemicals that cannot be synthesized by crustaceans (Kanazawa et al., 1988). However, it is required for ovarian maturation of the prawn broodstocks. Wouters et al., (2001) states that cholesterol functions in the endocrine system, which is a precursor of steroid hormones, Gonadal maturation, and growth. Besides rose myrtle, plants with steroids are cutleaf groundcherry (Physalis angulata).

Cutleaf cherryground ( $P$. angulata) is a garden plant used as medicinal plants for generations. The plant was used as a medicinal ingredient without identifying the chemical content contained in it. Thus, dose determination has not been effective. Sutjiatmo et al., (2011) mentioned that cutleaf cherryground leaves contain alkaloids, flavonoids, saponins, perifenols, steroids and triterpenoids, monoterpenoids, and sesquiterpenoids. Rohyani et al., (2015) reports that cutleaf cherryground contains steroid compounds. The use of chemical compounds in natural ingredients is not only nutritious but also has it side effects if the dose was incorrect.

The alkaloid, flavonoid, and steroid compounds were identified in $P$. angulata extract (Layyina, 2014). Alkaloid compounds can be utilized as an antibacterial Vibrio parahaemolyticus (Weliyadi et al., 2018). Awaludin and Ridwan (2016) reported that rose myrtle ethanol extract contained steroids that can increase the growth of tiger prawns. The bioactive content in cutleaf groundcherry leaves is necessary to be further researched because the content can be used as an alternative material in tiger prawn farming which hoped to prevent disease, accelerate growth and accelerate reproduction. Therefore, increasing tiger prawn production. Layyina (2014) states that $P$. angulate can be extracted with $\mathrm{n}$-hexane with an LC50 value of $3 \mathrm{ppm}$ proven through the Artemia salina test. Meanwhile, the toxicity value of $P$. angulata ethanol extract using post-larva remains unknown. Based on the description above, it is necessary to research the extraction to obtain basic information about bioactive compounds in cutleaf groundcherry and 
safe concentrations for the application of cutleaf ground cherry leaf extract in tiger prawn post-larvae. The study aims to identify secondary metabolite compounds in $P$. angulata and test the lethal dose of cutleaf groundcherry leaf extract on tiger prawn post-larvae.

\section{Materials and Method}

\section{1 Cutleaf groundcherry samples}

The samples of cutleaf cherryground leaves $(P$. angulata) were collected from Universitas Borneo Tarakan. The post-larva (PL) of 20 tiger prawns were obtained from the hatchery in Tarakan. The cutleaf cherry ground leave was extracted with $70 \%$ ethanol while the toxicity test used seawater.

\subsection{Cutleaf groundcherry extraction}

Cutleaf groundcherry leaves were extracted using the maceration method by immersing katuk-leave simplicia for three days (Ridwan et al., 2015) using 70\% ethanol solvent to enable polar and nonpolar compounds bound. The comparison of katuk-leave simplicia and solvents is $1: 3$. Drying cutleaf groundcherry leaves which were mashed by a blender, and soaking them in $70 \%$ ethanol for 3-4 days. Furthermore, the extract was filtered using a paper filter, and then evaporated using a rotary evaporator to separate the ethanol extract from the solvent.

\subsection{Chemical content test on cutleaf groundcherry leaf extract}

Cutleaf groundcherry extract compounds were identified using GC-MS Gas Chromatography-Mass Spectrophotometry with oven temperature $\left(50-290^{\circ} \mathrm{C}\right)$, Interface $0\left(290^{\circ} \mathrm{C}\right)$, control mode (split), pressure $(20.8$ psi), total flow $(23.7 \mathrm{ml} / \mathrm{min})$, split ratio (200:1), split flow $(199 \mathrm{ml} / \mathrm{min})$, gas (He), and detector (MSD).

\subsection{Toxicity test for ethanol extract of cutleaf groundcherry leaves}

Toxicity test, which employs the Brine Shrimp Lethality Test (BSLT) method, is an acute toxicity test for the toxic effects of a compound determined in a short period within 24 hours after administering the test dose (Sukardiman et al., 2004). The toxicity test of the $P$. angulata leaf ethanol extract used tiger prawn postlarvae. The toxicity test used Lethal Concentration 50
$\left(\mathrm{LC}_{50}\right)$. The ethanol extract of $P$. angulata leaves used five replications of the following concentrations of $100 \mathrm{ml} / \mathrm{l}$, $250 \mathrm{mg} / 1,500 \mathrm{mg} / \mathrm{l}, 750 \mathrm{mg} / \mathrm{l}$, and 1,000 mg/l. Before the process, the ethanol extract of cutleaf groundcherry leaves was dissolved with distilled water. A total of 20 tiger prawn post-larva were put into a container to be added with $P$. angulata extract and incubated for 24 hours. After the incubation, the dead tiger prawn postlarvae was counted, and the lethal concentration $\left(\mathrm{LC}_{50}\right)$ value was determined.

\section{Results and Discussion}

\subsection{Phytochemicals on cutleaf groundcherry leave extract}

Plant cells consist of two types of metabolites, i.e., primary metabolites (carbohydrates, amino acids, fats, and vitamins) and secondary metabolites, such as alkaloids, flavonoids, terpenoids, steroids, and tannins with varying amounts and compositions. Secondary metabolites are the largest source of pharmaceutical ingredients, food additives, perfumes, and pesticides. At present, the potential of various plants as herbal ingredients to improve health have been identified, and one of them is $P$. angulata. Physalis angulata is a wild plant that has not been widely used, especially in the fisheries field. Therefore, the analysis of compounds in cutleaf groundcherry leave extract was carried out as the first step to identify compounds potential for fisheries production. The chromatogram test results on cutleaf groundcherry leaves extract using GC-MS are presented in Figure 1 as follows.

The secondary metabolites on cutleafgroundcherry leaves had been reported in previous studies. Permana (2013) reported that cutleaf groundcherry ethanol extract contains several compounds, including alkaloids, flavonoids, and saponins. Djajanegara (2010) also reported that cutleaf groundcherry leaves contain alkaloids, flavonoids, saponins, and terpenoids.

The GC-MS analysis was conducted to find out the specific compound information contained in cutleaf groundcherry leaves ethanol extract. The selection of $70 \%$ ethanol as a solvent was a right step because ethanol is the best solvent for dissolving nutritious compounds found in plant cells (Djajanegara, 2008; Andianto et al., 2012). Several types of identified compounds are considered potential because they hold biological roles in supporting animal development and reproduction as presented in Table 1.

Sterol and steroid compounds were target compounds that were identified and believed to play 


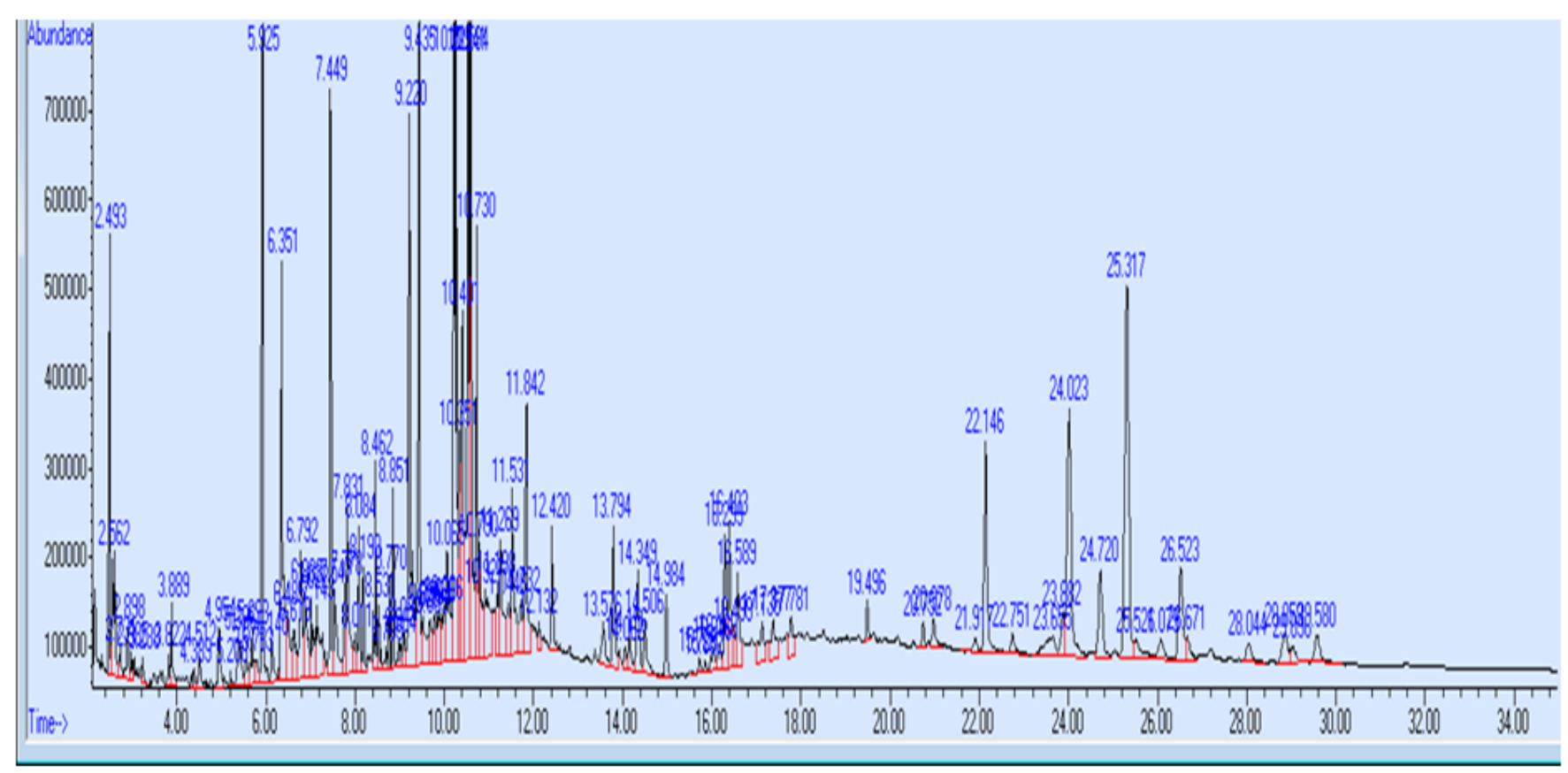

Figure 1. The Chromatogram results of the GC-MS analysis on cutleaf groundcherry leaves

a role in stimulating reproductive activity and animal development (Table 1). Sterols, commonly known as steroid alcohol (Millero and Sohn, 1992; Killops and Killops, 1993), are potential compounds due to their stability and structural diversity (Parrish et al., 2000). Sterols hold vital roles for cellular functions and become the initial substrate for fat-soluble vitamins and steroid hormones. Steroids are organic compounds of nonhydrolyzed sterol fat which are the reaction products of terpene or squalene derivatives (Hanani et al., 2005). Lisdawati (2002) reported that steroids can increase plant hormonal activities.

Also, the detected compound's potential for utilization were alkaloids and fatty acids. Alkaloid compounds had been widely used in the health field, such as pain relievers, antibiotics, nerve stimulants, and sedatives (Sumardjo, 2006). Types of alkaloids detected in cutleaf groundcherry leaf extracts were 1H-Indole, 3-methyl- (3-Methylindol). Those compounds specifically played a role in healing wounds or infections and acted as an antibacterial agent (Rupa et al., 2016).

Another type of compounds considered to hold an essential role in increasing fisheries production was fatty acid compounds. GC-MS result showed that fatty acids were dominant compounds found in extracts, reaching $50.99 \%$. The crucial fatty acid compound found in extracts include Octadecadienoic acid. Octadecadienoic acid or linoleic acid, known as omega- 6 fatty acid, is an essential fatty acid. The essential fatty acid is a kind of fatty acid that can't be produced by animal species (including humans).

These compounds are required to build and repair cell membrane, enabling cells to obtain optimal nutrition as well as remove harmful waste products.

Octadecadienoic acid or linoleic acid is an essential fatty acid in mammalian nutrition and is used in the biosynthesis of prostaglandins and the cell membranes. The prostaglandins (PGs) are substances with chemical structures that resemble hormones. Its role is quite crucial because prostaglandins are required in the reproductive system and wound healing process. Unlike hormones, prostaglandins are produced by the body only in certain conditions. Bardin (1970) reported that low $\mathrm{pH}$ levels were found on infertile men during ejaculation. The physiological role of PGs, in the reproductive system, is to facilitate the migration of spermatozoa from the vagina into the uterine cavity. It was explained that PGs can medicate infertility in humans.

The use of cutleaf groundcherry extract is believed to apply to prawns because it has beneficial chemical compounds for both the growth and reproduction processes. Therefore, it is necessary to carry out a toxicity test to determine the safe dose to ensure that this material is safe to be used as an additional ingredient in the feed, especially for tiger prawn larva. 
JIPK. Volume 11 No 2. November 2019 / Identification of Secondary Metabolites from Ethanol Extract of Ciplukan Leaves....

Table 1. Phytochemicals of the ethanol extract on cutleaf groundcherry leaves

\begin{tabular}{|c|c|c|c|c|c|}
\hline & $\begin{array}{l}\text { Classes of } \\
\text { Compounds }\end{array}$ & Retention Time & RI & $\%$ Areas & Compound Composition \\
\hline 1 & Sterol & 26.528 & 338892 & 1.36 & Stigmasta-5,24(28)-dien-3-ol, (3.b eta.,24Z)- \\
\hline \multirow[t]{2}{*}{2} & \multirow{2}{*}{ Sterol } & 24.030 & 332785 & 3.77 & Campesterol \\
\hline & & 25.321 & 331578 & 5.27 & DELTA. 24-24-METHYLCHOLESTER \\
\hline \multirow[t]{28}{*}{3} & \multirow{28}{*}{ Fatty acid } & 6.345 & 115375 & 2.73 & Dodecanoic acid (CAS) \$ \$ Lauric acid \$\$ \\
\hline & & 6.479 & 115375 & 0.76 & Dodecanoic acid (CAS) \$ \$ Lauric acid \$\$ \\
\hline & & 6.613 & 40245 & 0.47 & Hexanoic acid, ethyl ester \\
\hline & & 6.881 & 247750 & 0.93 & Nonadecanoic acid (CAS) \$\$ \\
\hline & & 7.150 & 157227 & 0.96 & Nonadecanoic acid (CAS) \\
\hline & & 7.837 & 157231 & 1.25 & Tetradecanoic acid \\
\hline & & 8.005 & 57829 & 0.26 & Butanoic acid, 3-methyl, 2-methyl propyl ester \\
\hline & & 8.524 & 176754 & 0.34 & Tetradecanoic acid \\
\hline & & 8.776 & 213928 & 0.34 & Hexanoic acid, ethyl ester \\
\hline & & 9.228 & 195432 & 3.76 & n-Hexadecanoic acid \\
\hline & & 9.429 & 231395 & 3.91 & Hexanoic acid, ethyl ester \\
\hline & & 9.681 & 228692 & 0.45 & Octadic-9-enoic acid \\
\hline & & 9.882 & 192794 & 0.54 & $\begin{array}{l}\text { 11-Dodecenoic acid, 2,4,6-trimethyl-, methyl } \\
\text { ester, (R,R,R)-(-)- }\end{array}$ \\
\hline & & 9.999 & 228696 & 0.68 & 9-Octadecenoic acid (Z)- (CAS) \$\$ \\
\hline & & 10.066 & 247862 & 1.23 & Heptadecanoic acid, ethyl ester $\$ \$$ \\
\hline & & 10.351 & 226097 & 1.26 & 9,12-Octadecadienoic acid (Z,Z)- \\
\hline & & 10.402 & 205838 & 2.49 & 7,10,13-Hexadecatrienoic acid, methyl ester \\
\hline & & 10.536 & 258928 & 4.07 & Linoleic acid, ethyl ester \\
\hline & & 10.586 & 256727 & 4.64 & $9,12,15$-Octadecatrienoic acid, ethyl ester \\
\hline & & 10.737 & 263348 & 1.92 & Octadecanoic acid, ethyl ester (CA \\
\hline & & 10.921 & 228691 & 1.34 & 9-Octadecenoic acid (Z)- (CAS) \\
\hline & & 11.190 & 136225 & 0.59 & Propanoic acid, 2-methyl-, nonyl ester \\
\hline & & 11.525 & 263143 & 1.43 & $\begin{array}{l}\text { Methyl ricinoleate } \$ \$ \text { Ricinoleic acid methyl } \\
\text { ester }\end{array}$ \\
\hline & & 12.413 & 263348 & 0.68 & Octadecanoic acid, ethyl ester (CAS) \\
\hline & & 13.788 & 281038 & 1.03 & Hexadecanoic acid, 2-hydroxy-1-(hy \\
\hline & & 14.978 & 263348 & 0.59 & Octadecanoic acid, ethyl ester (CAS) \\
\hline & & 16.302 & 203501 & 1.12 & E,Z-1,3,12-Nonadecatriene \\
\hline & & 16.587 & 304826 & 0.82 & Octadecanoic acid, 2-hydroxy-1-(hy \\
\hline \multirow[t]{3}{*}{4} & \multirow{3}{*}{ Alkaloid } & 17.040 & 224315 & 7.73 & Serine methyl ester, N-[2-oxo-4- \\
\hline & & 24.013 & 125869 & 4.28 & $\begin{array}{l}\text { 1H-Indole, 5-methyl-2-phenyl- \$ I ndole,5- } \\
\text { methyl-2-phenyl- \$\$ 2-Phenyl-5-methylindole } \\
\text { \$\$ 5-Methyl-2-phenylindole }\end{array}$ \\
\hline & & 5.389 & 292924 & 0.61 & Imidazole, 2-fluoro-1-triacetylrib ofuranosyl- \\
\hline
\end{tabular}

Table 2. Toxicity of cutleaf groundcherry extract to post tiger prawn larva as described in $\mathrm{LC}_{5}$

\begin{tabular}{llllc}
\hline No & $\begin{array}{c}\text { Concentration } \\
\text { Treatment }\end{array}$ & Mortality & $\begin{array}{c}\text { Lethal } \\
\text { Concentration }\end{array}$ & $\begin{array}{c}\text { Safe concentration (10\% of } \\
\text { the total lethal concentration) }\end{array}$ \\
\hline 1 & 100 & 38.75 & & \\
2 & 250 & 77.5 & & \\
3 & 500 & 96.5 & $131.0022 \mathrm{mg} / 1$ & $13.1002 \mathrm{mg} / 1$ \\
4 & 750 & 100 & & \\
5 & 1,000 & 100 & & \\
\hline
\end{tabular}




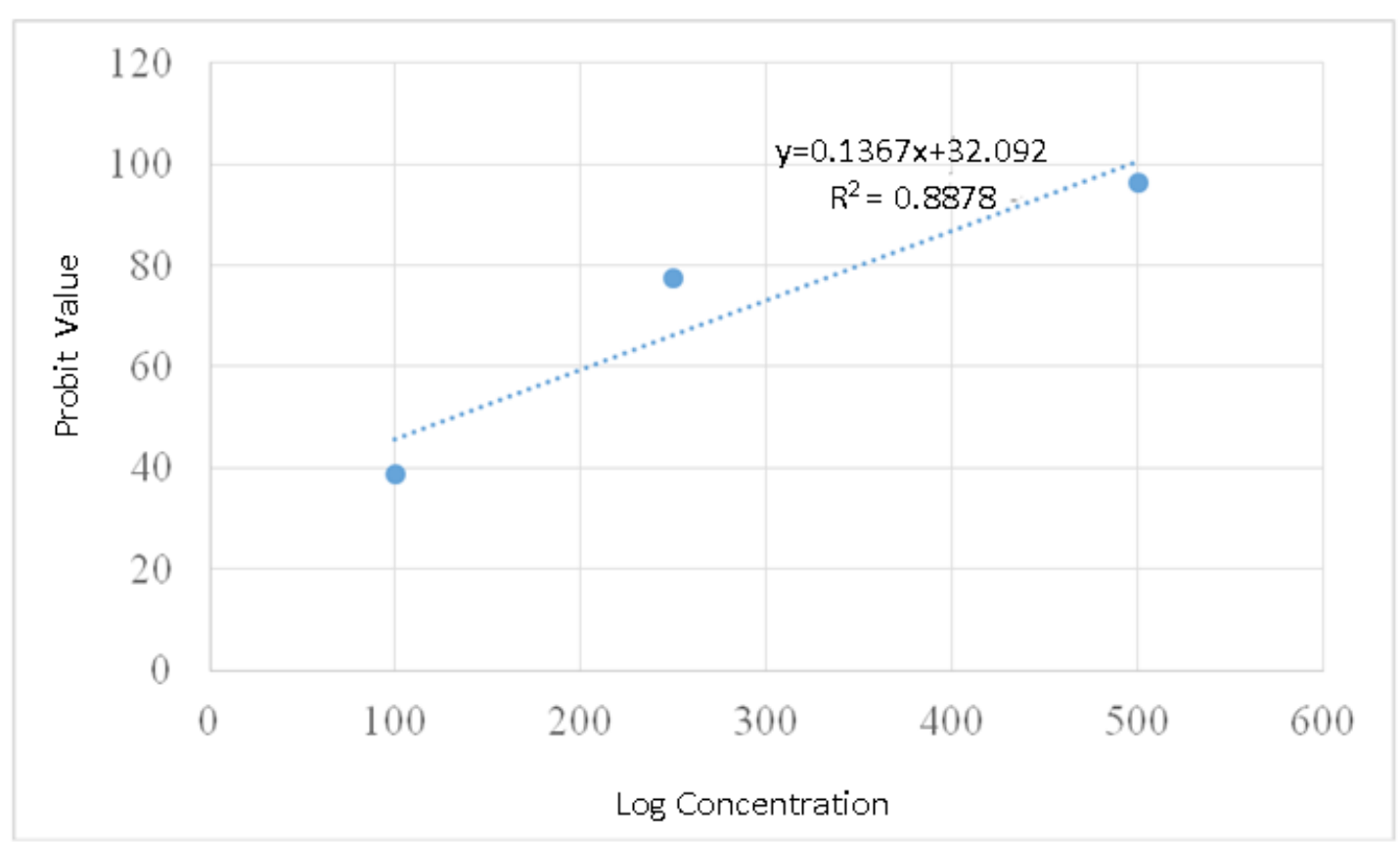

Figure 2. Log concentration of cutleaf groundcherry extract

\subsection{Toxicity of cutleaf groundcherry ethanol extract}

Observation of the toxicity test of toxicity of cutleaf groundcherry ethanol extract on tiger prawn larva as a test animal with various concentrations (100 $\mathrm{mg} / 1,250 \mathrm{mg} / 1,500 \mathrm{mg} / 1,750 \mathrm{mg} / 1$, and $1,000 \mathrm{mg} / \mathrm{l})$ for 24 hours was described through $\mathrm{LC}_{50}$ in Figure 2 as follows.

The regression equation for the $\mathrm{LC}_{50}$ test results of cutleaf groundcherry extract on tiger prawn larva obtained the formula $y=0.1367 x+32,092, R^{2}=0.8878$. Observation data on the results of the toxicity test $\left(\mathrm{LC}_{50}\right)$ on the ethanol extract of cutleaf groundcherry towards tiger prawn larva are shown in Table 2. The results showed that the mortality rate was directly proportional to the concentration extract. The $100 \%$ mortality rate was found at the concentrations of $750 \mathrm{mg} / \mathrm{l}$ and 1,000 $\mathrm{mg} / \mathrm{l}$, whereas less than $50 \%$ mortality rate was found in the treatment concentration of $100 \mathrm{mg} / \mathrm{l}$. The $\mathrm{LC}_{50}$ calculation results found that a $50 \%$ mortality rate of tiger prawn larva took place on the cutleaf groundcherry concentration of $131.0022 \mathrm{mg} / \mathrm{l}$.

Meyer et al., (1982) concluded that raw plant extracts are toxic if the $\mathrm{LC}_{50}$ value is more than 1,000 $\mathrm{mg} / \mathrm{ml}$, and non-toxic if the value is less than 1,000 $\mathrm{mg} / \mathrm{ml}$. Based on these results, the use of cutleaf groundcherry ethanol extract with high concentrations will cause death in prawns' larva. This matter is estimated as the result of active compounds found in this plant. Lilybeth and Nuñeza (2013) reported that when a higher concentration of plant extracts is used, the cytotoxic effect becomes stronger. This is due to the anti-tumor component contained in the plants. The lethal concentration of cutleaf groundcherry extract with ethanol solvent was $131.022 \mathrm{mg} / \mathrm{l}$. The safe concentration of cutleaf groundcherry ethanol extract was $13.1002 \mathrm{mg} / 1$.

\section{Conclusion}

Ethanol extract of $P$. angulata contains several compounds indicated to be beneficial in supporting the development and reproduction activities. Therefore, further research needs to be conducted for the growth and reproduction of tiger prawns. Also, $P$. angulata ethanol extract can be utilized due to its low toxicity.

\section{Acknowledgment}

The authors would like to extend their gratitude to the Ministry of Research, Technology and Higher Education as the fund grantor of the 2018 Junior Lecturer Research Fund

\section{Authors' Contributions}

Awaludin collected data and conducted a toxicity test. Yulma and Kartina collected data and extracted ciplukan. All authors discussed the results and contributed to the final manuscript. 


\section{Conflict of Interest} interests

The authors declare that they have no competing

\section{Funding Information}

This research was partially supported by Ministry for Research, Technology and Higher Education with grant number: No. 002 / UN51.9 / OPT / 2018 Contract Agreement No. 026 / UN51.9 / SP2H LT / 2018.

\section{References}

Aguilar-Guadarrama, A. B., \& Rios, M. Y. (2018). Flavonoids, Sterols and Lignans from Cochlospermum vitifolium and Their Relationship with Its Liver Activity. Molecules, 23(8): 1-8, 1952; https://doi. org/10.3390/molecules 23081952 .

Andrianto, D., Anaser, N., Untoro, M., Fatmawati, R., Winda, R. A., \& Aisyah, S. (2012). Pengaruh Ekstrak Daun Cutleaf groundcherry (Physalis angulata L.) terhadap Kelarutan Batu Ginjal in Vitro. Prosiding Seminar Nasional Kimia Unesa 2012-ISBN: 978-979-028-550-7.

Awaludin, \& Ridwan, A. (2016). Peningkatan Survival Rate Benih Udang Windu (Peaneus Monodon) Dengan Perendaman Ekstrak Etanol Karamunting (Melastoma Malabahricum). Jurnal Harpodon Borneo, 9(1): 32-35.

Bardin, T. P. (1970). The Role of Prostaglandin in Reproductive Physiology. Ohio State Medical Journal, 66(10): 1008-1012

Christie, W. W. (2019). Sterols 3. Sterols and Their Conjugates from Plants and Lower Organisms. http://www.lipidhome.co.uk/lipids/simple/plant-st/ index.htm.

Djajanegara, I., \& Wahyudi, P. (2010). Uji Sitotoksisitas Ekstrak Etanol Herba Ceplukan (Physalis angulata Linn.) terhadap Sel T47D secara in vitro. Jurnal Ilmu Kefarmasian Indonesia, 1: 41-47.

Djajanegara, I. (2008). Uji 70\% Ekstrak Etanol 70\% Herba Ceplukan (Physalis angulata Linn.) terhadap sel $70 \%$ secara in vitro. Jurnal Harpodon Valensi, 30(1): 1-8.

FAO Fisheries Information, Data and Statistics Unit (FIDI). (2017). Fishery Statistical Collection. FIGIS Data Collection. Rome: FAO.

Hanani, E., Mun'im, A., \& Sekarini, R. (2005). Identifikasi Senyawa Antioksidan dalam Spons Callyspongia sp Dari Kepulauan Seribu, Majalah Ilmu Kefarmasian, 2(3): 127-133.
Huberman. (2000). Shrimp endocrinology: a review. Aquaculture, 191: 191-208.

Idris, M. (2011). Energy pathway on two repeated spawning of Australian Red Claw Crayfish (Cherax quadricarinatus). $\mathrm{PhD}$ Thesis. Bandung: Institut Teknologi Bandung.

Kanazawa, A., Chim, L., \& Laubier. (1988). Tissue Uptake of Radioactive Cholesterol in the Prawn Penaeus japonicas Bate during Ovary Maturation. Aquatic Living Resources, 20(1): 85-91.

Keber, R., Rozman, D, \& Horvat S. (2013). Sterols in Spermatogenesis and Sperm Maturation. Journal of Lipid Research, (1): 20-33. doi: 10.1194/jlr. R032326.

Killops, S. D., \& Killopss, V. J. (1993). An Introduction to Organic Geochemistry. USA: Harlow Longman.

Kuballa, A., \& Elizur. (2007). Novel Molecular Approach to Study Moulting in Crustaceans. Bulletin of Fisheries Reearch Agency, 20: 5357.

Layyina H. (2014). Toksisitas Ekstrak Ciplukan (Physalis angulata) Berdasarkan Uji Letalitas Larva Udang. Skripsi. Bogor: Institut Pertanian Bogor.

Lilybeth, F., Olowa., O., \& Nuñeza, M. (2013). Brine Shrimp Lethality Assay of the Ethanolic Extracts of Three Selected Species of Medicinal Plants from Iligan City, Philippines International Research Journal of Biological Sciences, 11(2): 74-77.

Lisdawati, V. (2002). Buah Mahkota Dewa-Toksisitas, Efek Antioksidan, dan Efek Anti Kanker Berdasarkan Uji Penapisan Farmakologi. http:// www.mahkotadewa.com/ 7 diakses 17 Juli 2019.

Meyer, B. N., Ferrigni, N. R., Putnam, J. E., Jacobsen L.B., Nichols, D. E., \& Mc Laughlin, J. L. (1982). Brine Shrimp: A Convenientgeneral bioassay for Active Plant Constituents, Planta Medica, 45: 31-34.

Millero, F. S., \& Sohn, M. L. (1992). Chemical Oceanography. London: CRC Press.

Nawang, A., Trismawanti, I., \& Parenrengi, A. (2015). Produktivitas Telur dan Daya Tetas Induk Udang Windu (Penaeus monodon) Asal Aceh dan Takalar. Jakarta: Pusat Penelitian dan Pengembangan Perikanan Budidaya. pp: 701707.

Parrish, C. C., Abrajano, T. A., Budge, S. M., Helleur, R. J., Hudson, E. D., Pulchan, K. \& Ramos, C. (2000). Lipid and Phenolic Biomarkers in Marine Ecosystems: Analysis and Applications. Handbook of Enviromental Chemistry, 5: 193- 
223.

Permana, R. B. (2013). Aktivitas Antidiabetes Buah Ciplukan (Physalis angulata Linn.) Pada Tikus Model Diabetes Melitus Tipe-2. Skripsi. Bogor: Institut Pertanian Bogor.

Ridwan, A., Awaludin, \& Anggraeni. (2015). Gonadal Maturity Induction using Karamunting (Melastoma malabatrhicum) Ethanol Extract on white Shrimp Female (Litopenaeus vannamei). Proceeding of $6^{\text {th }}$. International Conference on Global Resources Conservation, (69-74). Malang: University of Brawijaya.

Ridwan, A., Awaludin., \& Wibowo, I. (2016). Potential Study of Ethanol Extract of Karamunting (Melastoma malabhatricum) As Growth Precursor for Larva of Giant Tiger Prawn (Penaues monodon) By Dipping Method. The 6th Basic Science International Conference. Malang.

Rohyani,I. S., Aryanti, E., \& Suripto.(2015). Kandungan Fitokimia Beberapa Jenis Tumbuhan Lokal yang Sering Dimanfaatkan sebagai Bahan Baku Obat di Pulau Lombok. Prosiding Seminar Nasional Masyarakat Biodiversitas Indonesia, 1 (2): 388-391.

Rupa, D., Yohana, C., Sulistyaningsih, D., \& Ratnadewi, D. (2017). Identification of Secretory Structure, Histochemistry and Phytochemical Compounds of Medicinal Plant Hyptis capitata Jacq. Journal of BIOTROPIA, 24(2): 94-103

Sukardiman, Abdul Rahman, \& Pratiwi N. F. (2004). Uji Praskrining Aktivitas Antikanker Ekstrak Eter dan Ekstrak Metanol Marchantia cf. planiloba Steph. Dengan Metode Uji Kematian Larva Udang dan Profil Densitometri Ekstrak Aktif. Majalah Farmasi Airlangga, 4(3): 90-100.

Sumardjo, D. D. (2006). Pengantar Kimia Buku Panduan Kuliah Mahasiswa Kedokteran. Jakarta: EGC
Sutjiatmo, A. B., Sukandar, E. Y., Ratnawati, Y., Kusmaningati, S., Wulandari, A., \& Narvikasari, S. (2011). Efek Antidiabetes Herba Ciplukan (Physalis Angulata Linn.) Pada Mencit Diabetes Dengan Induksi Aloksan. Jurnal Farmasi Indonesia, 5 (4): 166-171.

Singh, V. P., \& Sachan, N. (2011). Conjugated Lenoleic Acid: A Good Fat for Human Health.

A Review. International Journal of Dairy Science, 6: 165-171.

Waraporn, P., Piyakorn, B., \& Pornpimol, K. (2005). Histological Characterization of Cuticular Depositions throughout the Molting Cycle of the Black Tiger Shrimp (Penaeus monodon). Songklanakarin Journal Science and Technology, 27(3): 499-509.

Weliyadi, E., Awaludin, I., \& Maulianawati, D. (2018). Aktivitas Antibakteri Ekstrak Daging Kerang Bakau (Geloina coaxans) dari Kawasan Mangrove Tarakan terhadap Vibrio parahaemolyticus. Jurnal Pengolahan Hasil Perikanan Indonesia, 2 (1): 35-41.

Wen Xiao-bo, Ku Yao-mei, \& Zhou Kay-ya. (2003). Growth Response and Fatty Acid Composition ofJjuvenile Procambarus Clarkia Fed Different Source of Dietary Lipid. Agricultural Science in China, 2 (5): 583-590.

Wouters, R., Piguave, X., Bastidas, L., Calderon, J., \& Sorgeloos, P. (2001). Ovarian Maturation and Hemolymphatic Vitellogenin Concentration of Pacific White Shrimp Litopenaeus vannamei (Boone) Fed Increasing Levels of Total Dietary Lipids and HUFA. Aquaculture Research, 32: 573-582.

Wulandari, A., Pancoro, A., \& Suhandono, S. (2010). Construct and Production Gonad-Inhibiting Hormone dsRNA of Black Tiger Prawn (Penaeus monodon) by In vitro and In vivo Technique in L44440 Expression Vector. Master Thesis. Bandung: Institut Teknologi Bandung. 